\title{
Improvement of Read Aloud Skills for Elementary Students Through Literacy Corner
}

\author{
Nugraheti Sismulyasih S. B. \\ Primary School Education \\ Universitas Negeri Semarang, Indonesia \\ nugraheti@mail.unnes.ac.id
}

\author{
Hartati \\ Primary School Education \\ Universitas Negeri Semarang, Indonesia \\ hartati@mail.unnes.ac.id
}

\begin{abstract}
This study aimed to describe literacy corner arrangement in elementary schools and improve reading skills through the literacy corner. The research method used was quasi-experimental, with the design of one group pretest-posttest $\mathrm{O}_{1} \mathrm{X} \mathrm{O}_{2}$ (McMillan \& Schumacher, 1989). The subject of this research was the third grade students of SD LabSchool, Gajah Mungkur District, Semarang City. Data were collected by tests, questionnaires, and documentation. The results of this study were the initial ability to read aloud when the pretest was $42 \%$, then at the posttest it was $85 \%$, while students who had not completed reached $58 \%$ reduced to $15 \%$, this means that the literacy corner can be used to improve students' read aloud skills.
\end{abstract}

Keywords: read aloud, literacy corner, elementary school

\section{INTRODUCTION}

Reading activities are very important for everyone to get knowledge and experience, because the various information that is conveyed can we get by reading. In school, student reading skills are very influential on student learning success. Good reading skills will help students understand the text or reading. In elementary school, reading learning is followed by writing that start in the early grade. Reading and writing skills (literacy) are not owned suddenly, but are taught by the teacher in the school. If literacy learning (reading and writing) in the early grade does not have a strong foundation, then at the next reading stage students will face difficulties in following learning.

Reading and writing skills are basic skills for learning, because to obtain information depends on both of these abilities. Zuchdi and Budiasih (2001) revealed that the reading ability obtained in early reading will greatly affect the ability to read further. As the ability that underlies the next ability, the ability to read early requires teacher's attention. Early reading is the foundation for further learning. As a foundation, surely it must be strong and sturdy. Therefore, early read and write learning must be carried out seriously. Patience and thoroughness are needed in providing guidance and direction to students so that learning objectives can be achieved optimally.

But in reality, the language skills of elementary school students, especially the ability to read and write are still low. Rofi uddin and Zuhdi stated that to date, the mastery of elementary school literacy skills is still far from expectations. Likewise with Pelly (Haryadi and Zamzani, 1996) said that reading and writing lessons that were previously the main subjects and exercises are now getting less attention, both from students and teachers. Reading aloud learning is often ignored so that students' reading skills are low. The low ability to read aloud above is a problem faced by the teacher. If the problem is not solved immediately, then students will face difficulties in other aspects of the language such as listening, speaking, and writing.

The situation the researchers felt also when the researchers made observations, researchers found a problem with the low ability to read aloud. Most students still read monotone, regardless of good loud reading techniques (such as pronunciation, intonation, punctuation, and pauses). In addition, in reading aloud learning, the teacher does not use the media except the reading books. Even though it is known that elementary students according to Piaget (Syah, 2009) is at the end of the preoperational stage until the beginning of the formal operational stage which shows students' thinking tends to things that are concrete. Therefore the teacher must use the media in conveying learning including reading aloud learning. Based on these situation the researchers conducted research on learning read aloud by using literacy corner media

Read aloud is an activity that is a media for teachers, students, or readers together with other people or listeners to capture and understand the information, thoughts, and feelings of someone's author (Tarigan, 2008). In reading aloud, the reading process is done by voicing the written symbols on the reading. Read aloud is intended to train students to be able to read with proper pronunciation and intonation. Reading aload learning is more emphasized by loud reading learning by the teacher. In this case the teacher as a model, students pay attention to the teacher in reading aloud. After the teacher gives an example, students practice reading in turns or students can read aloud together first, then students read aloud individually.

The purpose of reading aloud was stated by Tarigan (2008), namely to find and obtain information, including content, understanding the meaning of reading. In accordance with this opinion, Akhadiah, et al (1992) also suggested that with adequate reading skills, they would be easier to extract information from various written sources. By reading, students will know and understand the meaning behind the contents of the reading. In addition, the purpose of the read aloud done by the teacher in learning can be: (1) give examples of recognizing and saying words, (2) giving examples of fluent and expressive reading, (3) helping students understand the contents of the reading, and (4) 
introducing various words, language structure and type of reading.

The benefits of read aloud are: (1) motivating students to start learning, (2) supporting simple reading and writing learning, (3) supporting learning material, (4) improving students' thinking skills, and (5) adding vocabulary and knowledge to students. The implementation of read aloud activities by reading stories can be done in four stages, namely: (1) The preparation phase, in the preparation stage that is done to choose the appropriate book, determine the purpose of reading, determine the flow of activities (initial activities, core, and closing); (2) The initial stage of reading includes activities to get students to know the book, discuss the author, title, background and character, ask the child to predict the contents of the story through the title of the book, explore students' general knowledge, if there is a picture, review the picture, submit a brief summary build meaning by conveying the short contents of the book, making comparisons with student knowledge; (3) Stage during reading, giving examples of reading aloud and right in pronunciation, pauses, gestures / gestures, expressions, as well as intonation, interacting, raising responses and discussions of students (the teacher can stop reading activities, asking students to convey understanding on readings that are heard, clarify and rectify misconceptions, and ask students to make further predictions on the continuation of the story); (4) The stage after reading aloud activities does not always have to be followed by further activities, but further activities can also be given. Follow-up activities are intended so students can continue their learning and understand reading.

Activities that can be selected and or developed, for example: (1) Give discussion questions (where is the location of the story ?, who is the main character? What is the problem? How do they get the solution? What do the authors want to say to us / the reader?) (2) Discuss the contents of the story (to increase understanding of the contents stories, students are asked to discuss the contents of the story with other students) (3) Discuss their responses to their stories and experiences, other story texts, and their knowledge of the world; (4) Retelling the contents of the story verbally, written and or in the form of images; (5) Students can also be asked to retell the contents of the story in the form of a story map (for example, by asking, what happened at the beginning, middle and end of the story?) (6) Invite students to answer imagination questions by imagining if they are characters (close your eyes, imagine you are the characters and experience everything, what will you do?) (7) Ask students to reflect on their understanding of the text; (8) Ask students to do think aloud (convey the results of thoughts on stories that are heard / listened orally and or written); (9) Teacher train students to improve their metacognitive abilities (inviting students to think about what their friends or other people think of the story being read) (10) Teachers can also provide fun questions (for example, who is your favorite character and why? If you rewrite the story and close the story, what will you change? If you can meet one of the characters in the story, who will you meet then what will you convey to him?) (11) Students can be given the task of conveying their understanding of reading by Think Aloud (expressing opinions and understanding of stories read orally and or written) and Writing Aloud (conveying students' understanding and ideas of reading in written form).

Literacy corner is the collection of textbooks and non-subject book collections without having to go back and forth to the library, because books are also available in the classroom. With the reading corner the class brings the book closer to students, and can foster students' interest in reading. Sources and Materials in literacy corners: (1) short stories of children, (2) children's novels, (3) poetry, (4) picture story books, (5) writing of individual student work, (6) articles from magazines, (7) articles from newspapers, (8) texts of information, (9) biographies, (10) autobiographies, (11) texts of speech, (12) historical documents, and (13) various contents of other selected stories.

\section{METHOD}

The method used in this study was a quasiexperimental method, with the design of one group pretest-posttest: $\mathrm{O}_{1} \times \mathrm{O}_{2}$ (Mc Millan \& Schumacher 1989: 312) Description: $\mathrm{O}_{1}$ : initial test; $\mathrm{O}_{2}$ : final test; $\mathrm{X}$ : Student understanding of literacy. The research conducted at Labschool UNNES Elementary School, Gajahmungkur District, Semarang City. The data collection in this study were: (a) tests, (b) questionnaires, and (3) documentation.

\section{RESULTS AND DISCUSSION}

Arrangement of literacy corner was not just collecting. The number of collections in the literacy corner was not enough to attract students to visit and do activities in it. A literacy corner located in the corner of the class must be decorated beautifully so that students feel at home lingering in it. With materials and equipment that were easily available. Literacy corners in the classroom were arranged and decorated beautifully and then given additional bookshelves to make it easier to put books according to the type of reading. In the literacy corner there were short stories, children's novels, poems, illustrated story books, Big Books, the work of students, magazines and others. The following was an example of a literacy corner (Figure 1).

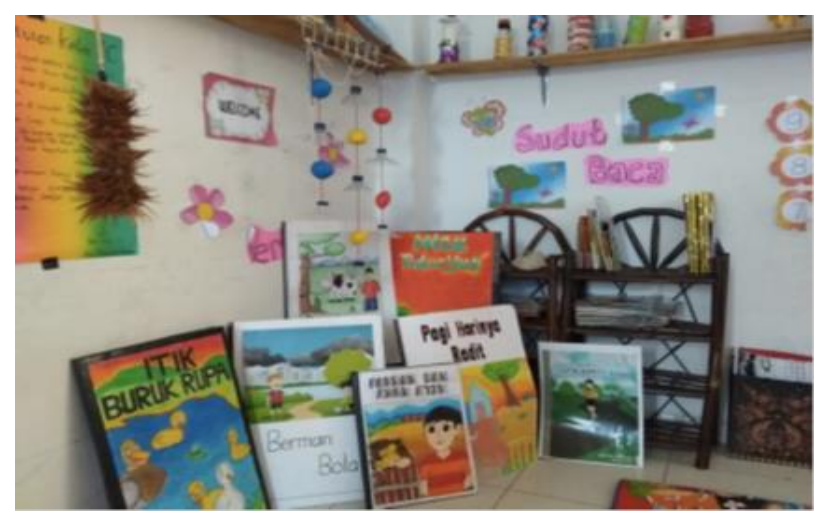

Figure 1

Literacy Corner

The way to maintain literacy corners was to periodically play collections in other classes. If collections from other classes have been read, the 
collection can be submitted to the library, then the literacy corner will be replaced by another collection. The results of the pretest obtained from the initial ability to read aloud students of Labschool Elementary School, Gajah Mungkur District as follows (Table 1).

Table 1

Pretest Results

\begin{tabular}{|c|l|c|}
\hline No & \multicolumn{1}{|c|}{ Accomplishment } & Initial Data \\
\hline 1 & Means & 61 \\
\hline 2 & Min. Score & 42 \\
\hline 3 & Max. Score & 83 \\
\hline 4 & Not Completed & $58 \%$ \\
\hline 5 & Completed & $42 \%$ \\
\hline
\end{tabular}

The data in Table 1 showed that the average initial ability before applyed read aloud learning using literacy corners was 61 with the lowest score of 42 and the highest score of 83 , complete scores $42 \%$ and $58 \%$ have not fulfilled the specified completeness. Based on the pretest above, the things that need to be considered were: (1) the teacher asked students to choose the preferred book, (2) the teacher should give examples of good and correct reading in pronunciation, pauses, gestures / gestures, expressions, and also intonation, (3) the teacher and students interacted (asked students to make a prediction of the continuation of the story, gave questions related to the reading text, (3) asked students to imitate the good and correct reading of the teacher, and (4) students alternately being asked to take turns reading using gestures and intonations right. Postes results read aloud students will be described in the Table 2 .

Table 2

Posttest Result

\begin{tabular}{|c|l|c|}
\hline No & \multicolumn{1}{|c|}{ Accomplishment } & Final Data \\
\hline 1 & Means & 81 \\
\hline 2 & Min. Score & 58 \\
\hline 3 & Max. Score & 100 \\
\hline 4 & Not Completed & $15 \%$ \\
\hline 5 & Completed & $85 \%$ \\
\hline
\end{tabular}

The data in table 2 showed that the means read aloud was 81 with the lowest score was 58, and the highest score was 100 , completeness $85 \%$ and $15 \%$ have not met the specified completeness (KKM 70). According to data obtained posttest, things that need to be emphasized in the implementation of read aloud using literacy corners through 4 stages as followed: (1) Preparation. The preparation starts from: (a) chosen a book (with pictures or without images) that was clear and focusing the attention of students, (b) determined the purpose of reading (what students want to introduce / understand), (c) written the scenario (for example: what page will be used as a prediction or question and answer); (2) The initial activity of reading, the initial reading activity consisted of: (a) invited students to know the book (title, author, background, character, etc.), (b) explored main students, (c) reviewed pictures, (d) submitted brief summaries of stories; (3) During reading, students focus on (a) reading position, (b) understanding punctuation, (c) read with gesture and good intonation; and (4) after read. After read the students have a discussion about the story and about their experiences. Based on the performance data read aloud using literacy corners in elementary school students, it can be concluded that the students' final ability in reading and writing increases the pretest and posttest value data were described as follows (Table 3 ).

Table 3

Student Read Aloud Skills

\begin{tabular}{|c|c|c|c|}
\hline No & Respondents & Pretest & Postest \\
\hline 1 & R-1 & 58 & 75 \\
\hline 2 & R-2 & 83 & 100 \\
\hline 3 & R-3 & 58 & 83 \\
\hline 4 & R-4 & 58 & 75 \\
\hline 5 & R-5 & 75 & 92 \\
\hline 6 & R-6 & 42 & 75 \\
\hline 7 & R-7 & 75 & 100 \\
\hline 8 & R-8 & 42 & 58 \\
\hline 9 & R-9 & 58 & 75 \\
\hline 10 & R-10 & 67 & 83 \\
\hline 11 & R-11 & 75 & 83 \\
\hline 12 & R-12 & 75 & 92 \\
\hline 13 & R-13 & 42 & 67 \\
\hline 14 & R-14 & 42 & 75 \\
\hline 15 & R-15 & 42 & 58 \\
\hline 16 & R-16 & 83 & 100 \\
\hline 17 & R-17 & 58 & 75 \\
\hline 18 & R-18 & 58 & 83 \\
\hline 19 & R-19 & 75 & 92 \\
\hline \multicolumn{2}{|r}{} & Means & $\mathbf{6 1}$ \\
\hline
\end{tabular}

Based on Table 3, the ability of read aloud used literacy corners got means in pretest 61 and posttest 81 , this means that all students could take part in learning activities carried out by the teacher with great enthusiasm. This was inseparable from the teacher's role in teaching literacy in the classroom. This was related to the promotion of the school literacy movement in Indonesia, especially in the K13 curriculum so that many schools were competed to make breakthroughs in the form of activities and fulfillment of facilities that lead to the school literacy movement. Thus it was necessary to increase the ability to read aloud to students.

\section{DISCUSSION}

Based on table data 2, the final means ability of read aloud used the reading corner was 81 with the lowest score was 58, the highest score was 100 , completeness $85 \%$ and $15 \%$ have not fulfilled the specified completeness (KKM 70). According to the data above, there was an increasing in learning outcomes and learning completeness from $42 \%$ to $85 \%$. Completion score was a score that describe the proportion and qualifications read aloud of students towards the competencies set in learning. Based on the score of student learning outcomes in the initial ability test showed that the percentage of classical learning completeness students have not reached $70 \%$. After being applied read aloud using the literacy corner it turned out that the percentage of students completeness reached $85 \%$ with the number of students completed learning were 16 students from 19 students. This could prove that used literacy corners increase the read ability of students. Through the literacy corner could make students more enthusiastic in reading. In the research that has been done it has been proven that there 
was an increase in the ability to read aloud used literacy corners. This could prove that literacy corners were able to improve students' read aloud abilities. Based on the results of tests conducted, it showed that there was an increase in read ability. So it could be concluded that the existence of a literacy corner in Labschool Elementary School in Gajah Mungkur District, Semarang City could contribute positively to the improvement of read aloud.

\section{CONCLUSION}

Based on the results of literacy corner research can improve students' Read Aloud ability. This can be seen from the increasing of learning outcomes and learning completeness from $42 \%$ to $85 \%$. The final means of ability after being applied read aloud using literacy corners was 81 with the lowest score was 58 , the highest score was 100 , completeness $85 \%$ has met the specified completeness (KKM 70). Through the literacy corner: (1) students have a place to take collections of textbooks and non-subject book without having to go back and forth to the library, because books are also available in the class; (2) bring the book closer to students; and (3) can foster students' interest in reading.

\section{REFERENCES}

[1] Allen, J., \& Gonzalez, K. 1998. There's Room for Me Here: Literacy Workshop in the Middle School. Ontario: Stenhouse Publishers.

[2] Anderson, R. C. 1972. Language Skills in Elementary Education. New York: Macmillan Publishing Co, Inc.

[3] Calkins, L. M. 2010.The Art of Teaching Reading. New York: Longman.

[4] Hoyt, L. 2007. Snapshots: Literacy Minilessons Up Close. New York: History Ink Books.

[5] Reutzel, D. R., \& Cooter, R. B. Jr. 2007. Strategies for reading assessment and instruction: Helping every child succeed (Third edition). Upper Saddle River, NJ: Pearson Education, Inc.

[6] USAID. 2014. Best Practices for Developing Supplementary Reading Materials: Final Report. New York: USAID.

[7] Williams College. 2014. Writting Programs. Retrieved 3 July 2019, from http://writingprograms.williams.edu/writingworkshop/.

[8] Zuchdi, D., \& Budiasih. 1996. Pendidikan Bahasa dan Sastra Indonesia di Kelas Rendah. Jakarta: Bumi Aksara. 